\title{
Tinjauan pustaka \\ Pemantauan Kerusakan Sendi pada Anak Hemofilia Berat: Peran Pemeriksaan Muskuloskeletal (HJHS), Ultrasonografi Sendi dan Kadar C-Terminal Telopeptide of Type II Collagen Urin
}

\author{
Teny Tjitra Sari, Novie Amelia Chozie, Djajadiman Gatot \\ Departemen Ilmu Kesehatan Anak Fakultas Kedokteran Universitas Indonesia /Rumah Sakit Cipto Mangunkusumo, Jakarta
}

\begin{abstract}
Hemartrosis dan artropati hemofilik merupakan morbiditas utama hemofilia. Patogenesis artropati hemofilik masih belum diketahui dengan jelas, diduga meliputi proses degenerasi dan inflamasi. Deteksi dini tahap awal artropati hemofilik sebelum timbul gejala klinis sangat diperlukan untuk mencegah progresivitas kerusakan sendi. Pemeriksaan muskuloskeletal dengan metode skoring Hemophilia Joint Health Score (HJHS) sensitif untuk mendeteksi artropati hemofilik tahap dini. Ultrasonografi sendi memiliki sensitivitas yang baik dalam mendeteksi artropati tahap dini, berbiaya lebih murah dan lebih praktis dibanding MRI. Peran petanda biologis kerusakan sendi seperti kadar C-terminal Telopeptide of Type II Collagen (CTX-II) urin sebagai penunjang diagnostik artropati tahap dini dan evaluasi keberhasilan terapi masih memerlukan penelitian lebih lanjut sebelum dapat digunakan dalam praktek sehari-hari. Tinjauan pustaka ini membahas patofisiologi dan pemantauan artropati hemofilik secara klinis, radiologis dan pemeriksaan petanda biologis kerusakan sendi. Sari Pediatri 2015;17(3):234-40.
\end{abstract}

Kata kunci: hemofilia, artropati, HJHS, ultrasonografi, CTX-II

\section{Review Article}

\section{Monitoring of Joint Damage in Haemophilia Weight Children: Role of Musculoskeletal Examination (HJHS), Ultrasound Joints and levels of C - Terminal Telopeptide of Type II Collagen Urine}

\author{
Teny Tjitra Sari, Novie Amelia Chozie, Djajadiman Gatot
}

\begin{abstract}
Hemarthrosis and hemophilic arthropathy are the main problems in severe hemophilia patients and may lead to physical disability and psychosocial issues. The pathogenesis of hemophilic arthropathy is not clearly understood, involving degenerative and inflammation process. Early detection before overt clinical symptoms is very important to prevent progressivity of joint damage. Hemophilia Joint Health Score (HJHS) examination developed by the World Federation of Hemophilia is sensitive to detect early stage arthropathy. Joint ultrasonography has good sensitivity, less costly and widely available compare to MRI in detecting early joint tissue damage. Urinary C-terminal telopeptide of type II collagen (CTX-II) as biomarker of joint cartilage degradation in hemophilic patients showed promising results for arthropathy diagnostic and monitoring treatment response as well as in osteoarthritis and rheumatoid arthritis, however further investigation is needed before it can be used as routine test in daily practice. This review article to discuss pathophysiology and monitoring of hemophilic arthropathy progressivity. Sari Pediatri 2015;17(3):234-40.
\end{abstract}

Keywords: hemophilia, arthropathy, HJHS, ultrasonography, CTX-II

\footnotetext{
Alamat korespondensi: Dr. Novie Amelia Chozie, SpA(K). Divisi Hematologi-Onkologi Departemen Ilmu Kesehatan Anak FKUI/RSCM. Jl. Diponegoro no 71, Jakarta Pusat 10430. E-mail:novie@ikafkui.net, novie.amelia@ui.ac.id
} 
$\mathrm{H}$

emartrosis merupakan morbiditas utama pada hemofilia A berat dan menjadi penyebab artropati hemofilik yang berujung pada nyeri kronis dan kecacatan. ${ }^{1}$ Walaupun terapi faktor pembekuan saat ini telah berkembang dengan adanya profilaksis, artropati hemofilik tetap menjadi masalah. Belum jelasnya patofisiologi dan kesulitan diagnosis dini artropati menyebabkan terapi yang ada saat ini belum sepenuhnya mampu mencegah dan mengatasi artropati hemofilik. Tinjauan pustaka ini bertujuan membahas patofisiologi artropati hemofilik yang menjadi dasar pemantauan secara klinis, status muskuloskeletal, pemeriksaan radiologis dan petanda biologis kerusakan sendi.

\section{Patofisiologi hemartrosis dan artropati hemofilik}

Hemartrosis pada hemofilia A berat dapat terjadi secara spontan dengan frekuensi 1-2 kali seminggu. Pada sekitar $90 \%$ penyandang hemofilia berat, perdarahan sendi pertama kali terjadi pada usia kurang dari 4 tahun, lebih dini dibandingkan hemofilia sedang dan ringan. ${ }^{2}$ Semula diduga bahwa patogenesis utama artropati hemofilik adalah proses degenerasi sendi, tetapi studi-studi selanjutnya menunjukkan bahwa selain degenerasi sendi yang mirip dengan osteoartritis, ditemukan bukti-bukti inflamasi seperti pada artritis reumatoid (gambar 1). ${ }^{3}$

Pada saat perdarahan, terjadi ekstravasasi sel darah merah dan leukosit ke dalam ruang sendi. Hemoglobin dan besi yang dilepaskan pada saat hemolisis akan difagosit oleh sel macrophage-like di jaringan sinovium. Sel neutrofil darah di dalam sendi menyebabkan inflamasi melalui sitokin-sitokin termasuk IL-1, IL-6 dan TNF (gambar 2). Selanjutnya darah akan diresorpsi oleh makrofag dan terjadi resolusi. Bila perdarahan berulang atau masif, kapasitas sel makrofag akan terlampaui sehingga komponen-komponen darah termasuk besi akan tetap berada di permukaan tulang rawan sendi. Peran besi dalam proses kerusakan selanjutnya belum jelas diketahui, namun akibat deposisi hemosiderin di sinovium dan subsinovium, sel-sel sinoviosit akan mengalami hipertrofi dan vili sinovium menebal, sehingga mengganggu difusi oksigen dan nutrisi dan menyebabkan suasana hipoksia di dalam sendi. Suasana hipoksia ini menyebabkan neovaskularisasi jaringan subsinovium sehingga makin mempermudah timbulnya perdarahan (mechanical bleeding) akibat ruptur vaskular. ${ }^{3,5}$ Adanya neovaskularisasi dibuktikan dengan peningkatan kadar plasma mediator angiogenik yaitu vascular endothelial growth factor (VEGF) dan matrix-metallopeptidase-9 pada pasien hemofilia dengan artropati, dibandingkan dengan kontrol orang sehat dan kelainan pembekuan darah tanpa artropati. ${ }^{6}$

Selain merusak sinovium, perdarahan sendi juga menyebabkan kerusakan rawan sendi bahkan sebelum inflamasi sinovium tampak jelas. Analisis biokimiawi dan metabolik memperlihatkan perubahan ireversibel namun subtle pada aktivitas metabolik sel kondrosit manusia, segera setelah pajanan terhadap darah (in vitro). ${ }^{8}$ Besi dapat menginduksi ekspresi aberrant dari proto-onkogen $c$-myc yang terlibat dalam proliferasi dan apoptosis sel. ${ }^{9}$ Pada studi in vitro, pajanan singkat selama 4 hari (yaitu waktu alamiah yang dibutuhkan

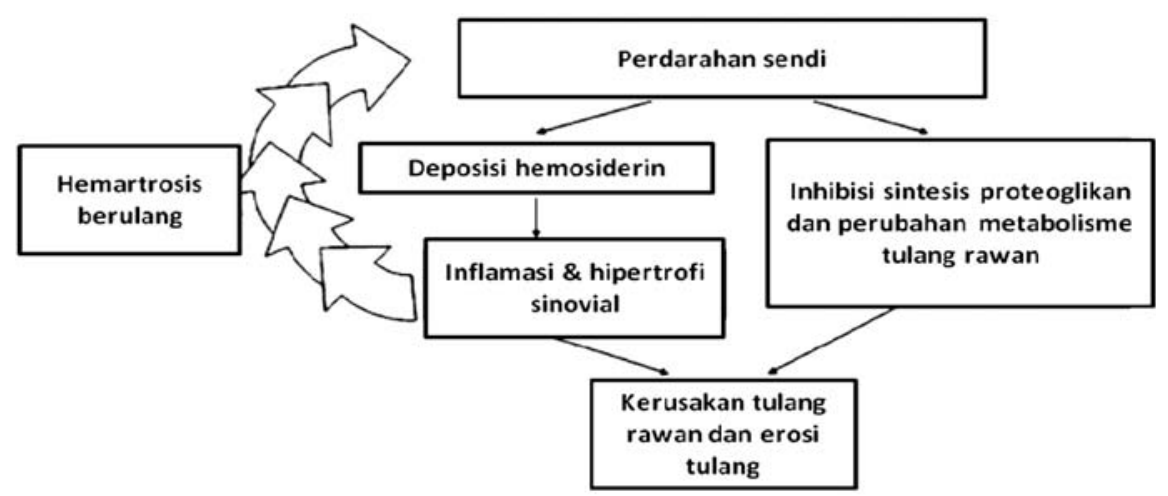

Gambar 1. Patofisiologi artropati hemofilik ${ }^{4}$ 


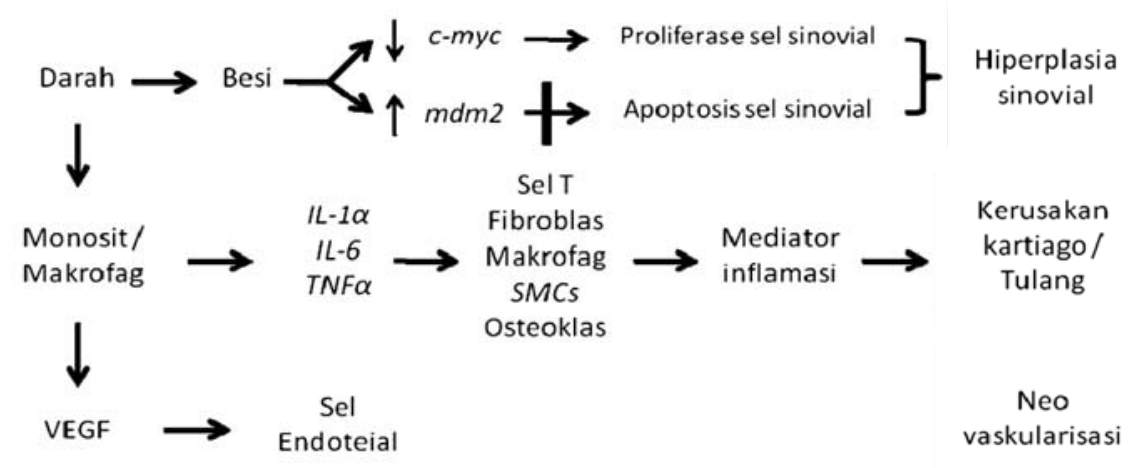

Gambar 2. Peran besi dalam kerusakan sendi ${ }^{7}$

untuk evakuasi darah dari ruang sendi) setelah perdarahan akan menginduksi kerusakan jangka panjang, yaitu inhibisi pembentukan matriks sendi (sintesis proteoglikan) dan peningkatan destruksi proteoglikan, sehingga komponen proteoglikan dalam matriks terus berkurang. Perubahan awal biokimiawi ini tidak diikuti dengan perubahan histologis maupun makroskopis jaringan yang dapat terlihat jelas. ${ }^{3}$ Pada studi lainnya diketahui bahwa setelah pajanan kartilago sendi manusia dan hewan selama 4 hari terhadap darah, pada minggu ke-10 terjadi perbaikan matriks kartilago, tidak ditemukan tanda inflamasi dan aktivitas destruksi sinovium. Dengan temuan ini, diduga dibutuhkan faktor tambahan lain (misalnya faktor mekanik atau perdarahan baru) untuk menginduksi kerusakan sendi permanen. ${ }^{10}$

\section{Pemantauan artropati pada hemofilia berat}

Pemantauan artropati hemofilik dapat dilakukan dengan pemeriksaan status muskuloskeletal secara klinis dan radiologis. Setiap metode pengukuran memiliki kelebihan dan kekurangan masing-masing, sehingga diperlukan penilaian secara menyeluruh atau gabungan untuk memperoleh hasil yang lebih akurat. Pemeriksaan lain seperti petanda biologis pada artropati hemofilik saat ini belum menjadi pemeriksaan standar dan masih memerlukan penelitian lebih lanjut. ${ }^{11}$

\section{- Pemantauan muskuloskeletal secara klinis}

Parameter klinis yang penting diperhatikan untuk pemantauan artropati adalah frekuensi perdarahan sendi, respons terapi faktor pembekuan, nyeri, perubahan bentuk sendi serta adanya gangguan fungsi sendi. Penilaian struktur dan fungsi muskuloskeletal yang klasik dilakukan dengan pengukuran range of motion (ROM) sendi. ${ }^{12}$ International Prophylaxis Study Group (IPSG) mengembangkan Hemophilia Joint Health Score (HJHS), yang terbukti sensitif dan dapat diterapkan sesuai perkembangan anak. ${ }^{13}$ Metode HJHS lebih sensitif mendeteksi kerusakan sendi tahap dini dibandingkan dengan WFH Physical Examination Scale yang dikembangkan tahun 1980,14 dan telah dibuktikan memiliki kehandalan dan kesahihan yang baik. ${ }^{13}$ Pemeriksaan HJHS seyogyanya dilakukan oleh tenaga medis (fisioterapis/dokter ahli) yang terlatih. ${ }^{14}$

Metode HJHS menilai struktur dan fungsi sendi lutut, siku dan pergelangan kaki, ketiganya bilateral (total 6 sendi). ${ }^{13,14}$ Kriteria penilaian meliputi 8 hal untuk setiap sendi, yakni derajat dan lamanya pembengkakan sendi, atrofi otot, kekuatan otot, krepitus pada pergerakan sendi, nyeri sendi, gangguan fleksi dan ekstensi sendi; ditambah dengan penilaian global gait pada saat berjalan, naik-turun tangga, berlari dan melompat dengan 1 tungkai. Rentang skor total adalah 0 -124, semakin besar skor HJHS menunjukkan kerusakan sendi semakin berat. ${ }^{15}$

Penilaian aktivitas dan kemandirian merupakan bagian dari penilaian status muskuloskeletal secara global. Untuk menilai aktivitas dan kemandirian telah dikembangkan Haemophilia Activities List (HAL) bagi pasien dewasa dan Pediatric Haemophilia Activities List (PedHAL) untuk anak, berupa kuesioner yang harus diisi oleh penyandang hemofilia berkaitan dengan 42 aktivitas pribadi sehari-hari. Hemophilia Activities List 
telah diuji untuk penyandang hemofilia dewasa dengan validitas yang baik, namun untuk PedHAL masih perlu divalidasi lebih lanjut. ${ }^{16,17}$ Instrumen lainnya yaitu Functional Independence Score in Haemophilia (FISH), menilai kemampuan fungsional penyandang hemofilia dibanding dengan orang normal. FISH dilaporkan memiliki korelasi yang baik dengan klinis $(r=-0,61)$ dan radiologis $(r=-0,38) \cdot{ }^{18,19}$

\section{- Pemeriksaan radiologis}

Gambaran radiologis konvensional (sinar-X) dapat digunakan untuk menilai derajat progresivitas kerusakan sendi, namun kurang sensitif untuk menilai tahap awal kerusakan sendi. ${ }^{20,} 21$ Pemeriksaan USG dan MRI lebih baik karena mampu memperlihatkan perubahan jaringan lunak dan osteokondral stadium dini. ${ }^{22-24}$ Pemeriksaan MRI sendi sampai saat ini masih merupakan penunjang terbaik dalam penilaian struktur sendi, namun mempunyai keterbatasan yaitu biaya mahal, memerlukan sedasi untuk anak dan tidak tersedia di semua rumah sakit. ${ }^{25}$

Pemeriksaan USG sendi makin berkembang luas dalam evaluasi sendi pasien hemofilia karena sensitivitasnya, baik dalam menilai jaringan lunak, biaya relatif murah, dan tersedia secara luas di rumah sakit. ${ }^{26}$ Pemeriksaan USG juga bermanfaat terutama untuk menilai sendi yang bengkak, untuk membedakan perdarahan sendi akut dengan sinovitis kronik tanpa perdarahan akut. ${ }^{27}$ Pada penelitian Klukowska dkk ${ }^{28}$ didapatkan korelasi yang baik antara derajat kerusakan kartilago sendi pada USG dan progresivitas perubahan tulang pada pemeriksaan sinar $X(r=0,71)$. Perubahan kartilago dan tulang sendi lutut pada penelitian ini meningkat sesuai dengan peningkatan frekuensi perdarahan sendi $(\mathrm{r}=0,67$ dan $\mathrm{r}=0,73) .^{28}$

Penelitian Muça-Perja dkk ${ }^{26}$ mengevaluasi 325 sendi (115 sendi pergelangan kaki dan 210 sendi lutut) pada 111 pasien berusia 7-80 tahun. Pada penelitian tersebut kelainan sendi tersering adalah hipertrofi sinovium (88\%) dan kelainan kartilago (76\%) pada lutut, yang merupakan perubahan tahap awal artropati. Sierra Aisa dkk. ${ }^{29}$ membandingkan pemeriksaan USG dengan MRI sendi pada 61 pasien hemofilia berusia 4-82 tahun. Pada pasien hemofilia berat, MRI dan USG memperlihatkan kemampuan yang sama dalam menilai sendi normal $(=1,000)$. Terdapat korelasi yang baik (uji Pearson) antara USG dan MRI dalam mendeteksi hiperplasia sinovium/ deposit hemosiderin ( $=0,839$ pada pergelangan kaki dan $=1,000$ pada lutut $)$ dan erosi sendi $(=0,850$ pada pergelangan kaki dan $=1,000$ pada lutut). Deteksi kista tulang $(=0,552-0,643)$ dan cartilage loss $(=0,462-0,643)$ lebih baik pada pemeriksaan MRI daripada USG. Sierra Aisa $\mathrm{dkk}^{29}$ menyimpulkan USG bermanfaat dalam deteksi perdarahan sendi, hyperplasia sinovium dan erosi sendi dengan hasil yang sebanding dengan MRI, sehingga dapat digunakan dalam pemantauan dan evaluasi perdarahan dan struktur sendi pasien hemofilia.

Martinoli $\mathrm{dkk}^{30}$ mengembangkan metode ultrasonografi dengan sistem skoring yang disebut Haemophilia early arthropathy detection with ultrasound (HEAD-US) untuk menilai sendi siku, lutut dan pergelangan kaki, dengan tujuan meningkatkan sensitivitas ultrasonografi dalam mendeteksi tanda artropati dini menggunakan teknik yang sistematis, mudah dan cepat. Metode ini disusun berdasarkan konsensus panel ahli menggunakan data berbasis bukti dan komprehensif. Rentang skor total adalah 0-8 untuk setiap sendi. Metode ini diharapkan dapat menjadi pilihan untuk diagnosis dan pemantauan terapi.

Bagi negara berkembang seperti Indonesia, pemeriksaan USG berpotensi menjadi penunjang yang penting dalam evaluasi sendi pasien hemofilia, dengan segala kelebihan dan kekurangannya dibandingkan MRI.

\section{- Pemeriksaan petanda biologis sebagai penunjang diagnostik artropati}

Dalam dua dekade terakhir, banyak penelitian dilakukan pada pasien osteoartritis (OA) dan artritis reumatoid (AR) mengenai $C$-terminal telopeptide of type II collagen (CTX-II) untuk menilai kerusakan sendi. ${ }^{31}$ C-terminal telopeptide of type II collagen adalah ujung terminal $\mathrm{C}$ dari rantai propeptida yang dihasilkan pada proses degradasi kartilago sendi dan diekskresi melalui urin (Gambar 3). Kadar CTX-II urin meningkat sesuai dengan progresivitas $\mathrm{OA}$ dan $\mathrm{AR}^{32,33}$ sehingga dapat digunakan sebagai petanda dini efikasi terapi dan memprediksi progresivitas kedua penyakit tersebut. ${ }^{34}$

Jansen $\mathrm{dkk}^{35}$ melaporkan hasil penelitian pada 36 pasien artropati hemofilik berusia $35 \pm 2$ tahun, bahwa kombinasi kadar CTX-II urin, kadar serum cartilage oligomeric matrix protein (COMP) dan kadar serum chondroitin sulfate 846 (CS-846) berkorelasi baik dengan hasil pemeriksaan radiologis yaitu skor 
(a)

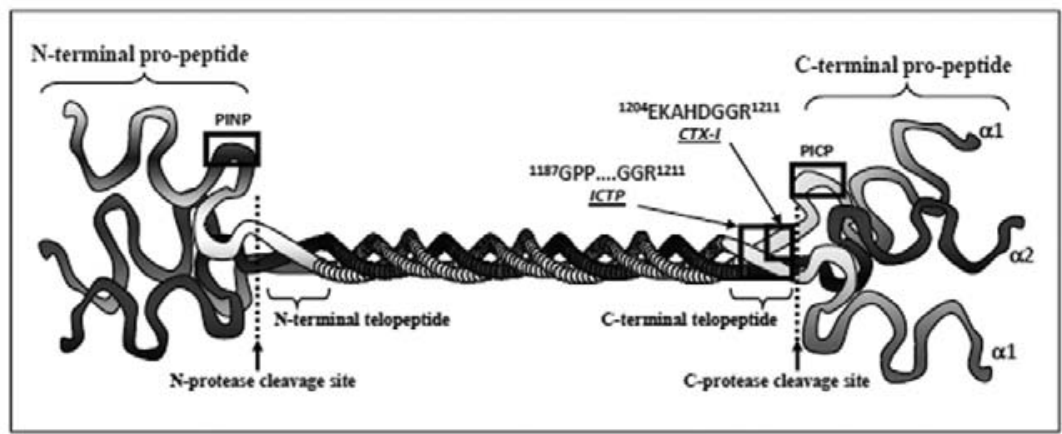

(b)

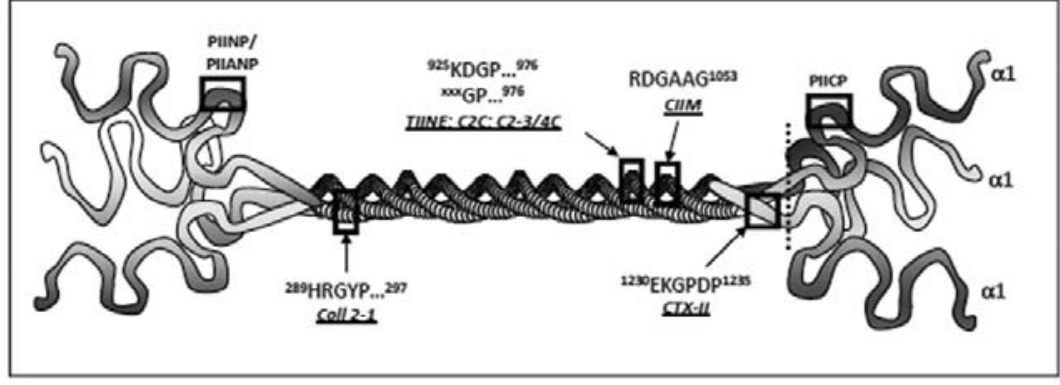

Gambar 3. (a) Protease-Generated Neoepitopes pada Aggrecan dan Kolagen tipe I dan (b)

Protease-Generated Neoepitopes pada Aggrecan dan Kolagen tipe II. ${ }^{36}$

Pettersson total $(\mathrm{r}=0,672 ; \mathrm{p} \leq 0,001)$ dan komponen penyempitan ruang sendi pada skor tersebut $(r=0,698$; $\mathrm{p} \leq 0,001)$. Disimpulkan bahwa kombinasi ketiga petanda ini dapat menjadi parameter proses degenerasi dan progresivitas perubahan kartilago pada artropati hemofilik.

Penelitian van Vulpen $\mathrm{dkk}^{17}$ pada canine dan manusia penyandang hemofilia menunjukkan peningkatan kadar CTX-II urin yang bermakna pada hari ke-2 sampai ke-5 pasca hemartrosis akut, kemudian menurun hingga mencapai kadar awal pada hari ke-14. Pada penelitian tersebut kadar COMP dan CS-846 serum tidak menunjukkan perubahan yang bermakna.

Publikasi hasil penelitian tentang CTX-II pada hemofilia masih sangat sedikit, namun menunjukkan bukti-bukti yang mendukung hubungan kadar CTXII dengan artropati hemofilik. Penelitian CTX-II pada OA maupun hemofilia dilakukan pada subjek dewasa, hingga saat ini belum ada data pada anak. Masih diperlukan penelitian lebih lanjut mengenai kadar CTX-II urin sebelum dapat digunakan secara rutin untuk pemantauan dan evaluasi artropati pada anak hemofilia.

\section{Kesimpulan}

Hemartrosis dan artropati hemofilik merupakan morbiditas utama hemofilia. Patogenesis artropati hemofilik masih belum diketahui dengan jelas, diduga meliputi proses degenerasi dan inflamasi. Deteksi dini tahap awal artropati hemofilik sebelum timbul gejala klinis sangat diperlukan untuk mencegah progresivitas kerusakan sendi. Pemeriksaan ultrasonografi sendi memiliki sensitivitas yang baik dalam mendeteksi artropati tahap dini, berbiaya lebih murah dan lebih praktis dilakukan pada anak penyandang hemofilia dibanding MRI. Peran petanda biologis kerusakan sendi sebagai penunjang diagnostik artropati tahap dini dan evaluasi keberhasilan terapi juga masih memerlukan penelitian lebih lanjut sebelum dapat digunakan dalam praktek sehari-hari.

\section{Daftar pustaka}

1. Srivastava A, Brewer AK, Mauser-bunschoten EP, Key NS, Kitchen S. Treatment guidelines working group on behalf of the world federation of hemophilia: guidelines 
for the management of hemophilia. Haemophilia 2013;19:1-47.

2. van Dijk K, van der Bom JG, Fischer K, Grobbee DE, van den Berg HM. Variability in clinical phenotype of severe haemophilia: The role of the first joint bleed. Haemophilia 2005;11:438-43

3. Roosendaal G, Lafeber FP. Pathogenesis of haemophilic arthropathy. Haemophilia 2006;12:S117-21.

4. Raffini Leslie, Catherine M. Modern management of haemophilic arthropathy. Br J Haematol 2007;136:77787.

5. Forsyth AL, Rivard GE, Valentino LA, Zourikian N, Hoffman M, Monahan PE, dkk. Consequences of intraarticular bleeding in haemophilia: Science to clinical practice and beyond. Haemophilia 2012;18:S112-9.

6. Acharya SS, Kaplan RN, Macdonald D, Fabiyi OT, DiMichele D, Lyden D. Neoangiogenesis contributes to the development of hemophilic synovitis. Blood 2011;117:2484-93.

7. Rodriguez NI, WK H. Advances in hemophilia: Experimental aspects and therapy. Pediatr Clin N Am 2008;55:357-76.

8. Hooiveld MJJ, Roosendaal G, van den Berg HM, Bijlsma JWJ, Lafeber FPJG. Hemoglobin-derived irondependent hydroxyl radical formation in blood induced joint damage: An in vitro study. Rheumatology 2003;42:784-90.

9. Wen FQ, Jabbar AA, Chen YX, Kazarian T, Patel DA, Valentino LA. $c-m y c$ proto-oncogene expression in hemophilic synovitis: In vitro studies of the effects of iron and ceramide. Blood 2002;100:912-6.

10. Hooiveld MJJ, Roosendaal G, van den Berg HM, Bijlsma JWJ, Lafeber FPJG. Blood-induced joint damage: Long-term effects in vivo and in vitro. J Rheumatol 2003;30:339-44.

11. Lambert T AG BG, Hedner U, Yuste VJ, Ljung R, dkk. Joint disease, the hallmark of haemophilia: What issues and challenges remain despite the development of effective therapies? Thromb Res 2014;133:967-71.

12. Soucie JM, Cianfrini C, Janco RL, Kulkarni R, Hambleton J, Evatt B, dkk. Joint range-of-motion limitations among young males with hemophilia: Prevalence and risk factors. Blood 2004;103:2467-73.

13. Hilliard P, Funk S, Zourikian N, Bergstrom BM, Bradley CS, McLimont M, dkk. Hemophilia Joint Health Score reliability study. Haemophilia 2006;12:518-25.

14. Feldman BM, Funk S, Lundin B, Doria AS, Ljung R, Blanchette V, dkk. Musculoskeletal measurement tools from the International Prophylaxis Study Group (IPSG).
Haemophilia 2008;14:162-9.

15. Group IPS. Physical Therapy Expert Working Group. Hemophilia Joint Health Score 2011:1-31.

16. van Genderen FR, Westers P, Heijnen L, de Kleijn P, van den Berg HM, Helders PJ, dkk. Measuring patients' perceptions on their functional abilities: validation of the haemophilia activities list. Haemophilia 2006;12:3646.

17. van Genderen FR, van Meeteren NL, van der Bom JG, Heijnen L, de Kleijn P, van den Berg HM, dkk. Functional consequences of haemophilia in adults: The development of the Haemophilia Activities List. Haemophilia 2004;10:565-71.

18. Poonnoose PM, Thomas R, Keshava SN, Cherian RS, Padankatti S, Pazani D, dkk. Psychometric analysis of the Functional Independence Score in Haemophilia (FISH). Haemophilia 2007;13:620-6.

19. Poonnoose PM, Manigandan C, Thomas R, Shyamkumar NK, Kavitha ML, Bhattacharji S, dkk. Functional Independence Score in Haemophilia: A new performancebased instrument to measure disability. Haemophilia 2005;11:598-602.

20. Pettersson H, Ahlberg A, Nilsson IM. A radiologic classification of hemophilic arthropathy. Clin Orthop Relat Res 1980;149:153-9.

21. Doria AS, Lundin B, Miller S, Kilcoyne R, Dunn A, Thomas S, dkk. Expert imageing working group of the international prophylaxis study group: Reliability and constructvalidity of the compatible MRI scoring system for evaluation of elbows in haemophilic children. Haemophilia 2008;14:303-14.

22. Keshava S, Gibikote S, Mohanta A, Doria AS. Refinement of a sonographic protocol for assessment of haemophilic arthropathy. Haemophilia 2009;15:1168-71.

23. Zukotynski K, Jarrin J, Babyn PS, Carcao M, Pazmino Canizares J, Stain AM, dkk. Sonography for assessment of haemophilic arthropathy in children: A systematic protocol. Haemophilia 2007;13:293-304.

24. Solimeno L, Goddard N, Pasta G, Mohanty S, Mortazavi S, Pacheco L, dkk. Management of arthrofibrosis in haemophilic arthropathy. Haemophilia 2010;16:11520.

25. Cross S, VaidyaS, Fotiadis N. Hemophilic arthropathy : A review of imaging and staging. Semin Ultrasound CT MRI 2013;34:516-24.

26. Muca-Perja M, Riva S, Grochowska B, Mangiafico L, Mago D, Gringeri A. Ultrasonography of haemophilic arthropathy. Haemophilia 2012;18:364-8.

27. Querol F, Rodriguez-Merchan EC. The role of 
ultrasonography in the diagnosis of the musculo-skeletal problems of haemophilia. Haemophilia 2012;18:e21526.

28. Klukowska A, Czyrny Z, Laguna P, Brzewski M, Serafin-Krol MA, R. R-M. Correlation between clinical, radiological and ultrasonographical image of knee joints in children with haemophilia. Haemophilia 2001;7:28692.

29. Sierra Aisa C, Lucia Cuesta JF, Rubio Martinez A, Fernandez Mosteirin N, Iborra Munoz A, Abio Calvete $\mathrm{M}$, dkk. Comparison of ultrasound and magnetic resonance imaging for diagnosis and follow-up of joint lesions in patients with haemophilia. Haemophilia 2014;20:51-7.

30. Martinoli C, Alberighi, O. D. C., Di M. G, Graziano, E., dkk. Development and definition of a simplified scanning procedure and scoring method for Haemophilia Early Arthropathy Detection with Ultrasound (HEADUS). Thrombosis and Haemostasis 2013;109:117079.

31. Christgau S, Garnero P, Fledelius C, Moniz C, Ensig M, Gineyts E, dkk. Collagen Type II C-telopeptide fragments as an index of cartilage degradation. Bone 2001;29:209-15.

32. Tanishi Nobuchika, Yamagiwa Hiroshi, Hayami Tadashi, Mera Hisashi, Koga Yoshio, Omori Go, dkk. Usefulness of urinary CTX-II and NTX-I in evaluating radiological knee osteoarthritis : the Matsudai knee osteoarthritis survey. J Orthop Sci 2014;19:429-36.

33. Duclos ME, Roualdes O, Cararo R, Rousseau JC, Roger T, DJ. H. Significance of the serum CTX-II level in an osteoarthritis animal model: A 5-month longitudinal study. Osteoarthritis and Cartilage 2010;18:1467-76.

34. Landewe' Robert, Geusens Piet, Boers Maarten, van der Heijde De'sire'e, Lems Willem, te Koppele Johan, dkk. Markers for Type II Collagen breakdown predict the effect of disease-modifying treatment on long-term radiographic progression in patients with rheumatoid arthritis. Arthritis Rheum 2004;50:1390-9.

35. Jansen NWD, Roosendal G, Lundin B, Heijnen L, Mauser-Bunschoten E, Bijlsma JWJ, dkk. The combination of the biomarkers urinary C-terminal telopeptide of type II collagen, serum cartilage oligomeric matrix prtotein and serum chondroitin sulfate 846 reflects cartilage damage in hemophilic arthropathy. Arthritis Rheum 2009;60:290-8.

36. Karsdal Morten A, Woodworth Thasia, Henriksen Kim, Maksymowych Walter P, Genant Harry, Vergnaud Philippe, dkk. Biochemical markers of ongoing joint damage in rheumatoid arthritis - current and future applications, limitations and opportunities. Arthritis Res Ther 2011;13:1-20. 